\title{
Pengaruh Kebijakan Dividen terhadap Harga Saham (Studi pada Perusahaan Pertambangan di Bursa Efek Indonesia)
}

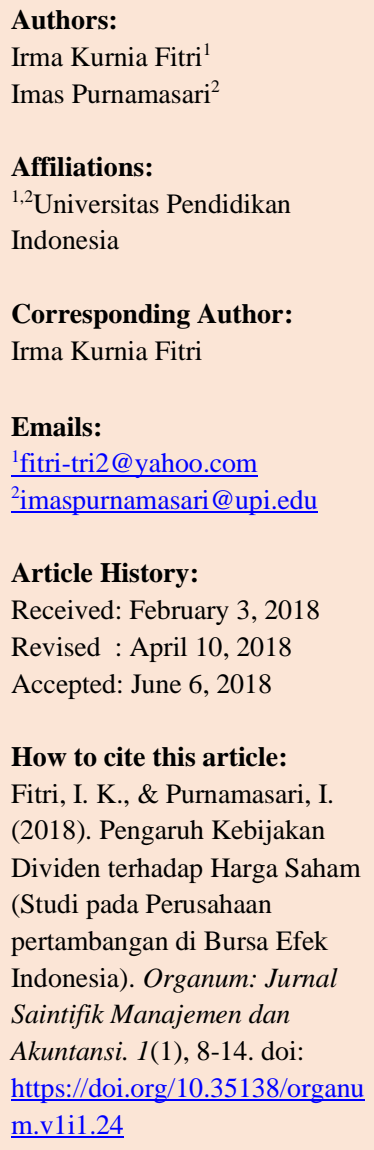

How to cite this article: Fitri, I. K., \& Purnamasari, I. (2018). Pengaruh Kebijakan Dividen terhadap Harga Saham (Studi pada Perusahaan pertambangan di Bursa Efek Indonesia). Organum: Jurnal Saintifik Manajemen dan Akuntansi. 1(1), 8-14. doi: https://doi.org/10.35138/organu $\underline{\text { m.v1i1.24 }}$

\section{Journal Homepage:} ejournal.winayamukti.ac.id/ind ex.php/Organum

\section{Copyright:}

(C) 2018. Published by Organum: Jurnal Saintifik Manajemen dan Akuntansi. Faculty of Economics and Business. Winaya Mukti University.
Abstract. Dividend policy is a decision that can be taken by the company in deciding whether the profit earned will be distributed in the form of dividends or retained for reinvestment. Bonuses could be used as a signal by investors to make investment decisions that will affect the company's stock price. The main purpose of this study is to identify whether dividend policy could convey information to the market which generates a reaction on stock prices. Research methods used descriptive and verification. An indicator of dividend policy was the dividend payout ratio, and stock prices used in this study was the closing share price. Samples in this study were ten mining companies on the Indonesia Stock Exchange that regularly pay dividends in 2008-2012. Analysis of the data used was a simple linear regression. Based on the research showed that the dividend policy affected stock prices.

Keywords: Dividend policy; stock prices; signaling theory.

Abstrak. Kebijakan dividen merupakan suatu keputusan yang dapat diambil perusahaan dalam memperlakukan laba yang diperoleh apakah akan dibagikan dalam bentuk dividen atau ditahan untuk reinvestasi perusahaan. Tujuan utama dari penelitian ini adalah untuk mengidentifikasi apakah kebijakan dividen menyampaikan informasi ke pasar yang menghasilkan reaksi terhadap harga saham. Metode penelitian menggunakan metode deskriptif verivikatif. Indikator kebijakan dividen adalah dividend payout ratio dan harga saham yang digunakan adalah harga saham penutupan. Sampel dalam penelitian 10 perusahaan pertambangan yang rutin membagikan dividen selama 2008-2012. Analisis data yang digunakan adalah regresi linier sederhana. Berdasarkan hasil analisis kebijakan dividen berpengaruh positif terhadap harga saham. Penelitian ini membuktikan bahwa kebijakan dividen dijadikan sebagai sinyal oleh para investor dalam mengambil keputusan investasi yang pada akhirnya akan berpengaruh terhadap harga saham perusahaan. Penelitian ini mendukung signaling teory.

Kata Kunci: Kebijakan dividen; harga saham; teori pensinyalan.

\section{Pendahuluan}

$\mathrm{P}$ erforma harga saham pertambangan terus tertekan merespon kebijakan pemerintah yang dinilai tidak menguntungkan perusahaan pertambangan dan penurunan harga komoditas di pasar Internasional. Indeks harga saham di sektor pertambangan mulai menurun pada April dan Mei. Indeks harga saham di sektor pertambangan ini bahkan sempat naik ke level 2804,1 pada Februari. Akan tetapi, indeks tersebut mengalami penurunan sebesar 6,6 persen (MoM) pada April dan sebesar 19,9 persen (MoM) pada Mei. Sehingga, dari awal tahun hingga Oktober 2012 indeks harga saham di sektor 
pertambangan turun sebesar 29,2 persen. (financeroll.co.id. diakses pada 24 Juni 2013, 10:30).

Kondisi pasar yang saat ini dalam keadaan yang baik banyak dimanfaatkan investor untuk melakukan penanaman modal pada perusahaan yang dinilai cukup menjanjikan. Hal tersebut dapat dilihat dari nilai bersih transaksi saham yang dilakukan oleh investor asing. Sepanjang tahun 2011 terjadi aliran masuk dana asing sebesar Rp. 15,44 triliun hingga 27 Desember 2012. Dana asing tersebut berhasil menaikan harga saham dari 7 sektor industri di Bursa Efek Indonesia. 7 sektor tersebut yaitu Basic Industry, Miscellaneous, Consumer Good, Property and Real Estate, Infrastructure, Finance, Trade Service. Sedangkan untuk 2 sektor berikutnya mengalami penurunan harga saham di tahun yang sama, 2 sektor tersebut yaitu Mining dan Agriculture. Adapun kondisi dari pergerakan harga saham berdasarkan sektor perusahaan di Bursa Efek Indonesia terdapat pada Gambar 1.

\section{Gambar 1. Harga Saham Berdasarkan Klasifikasi Industri 2007-2012}

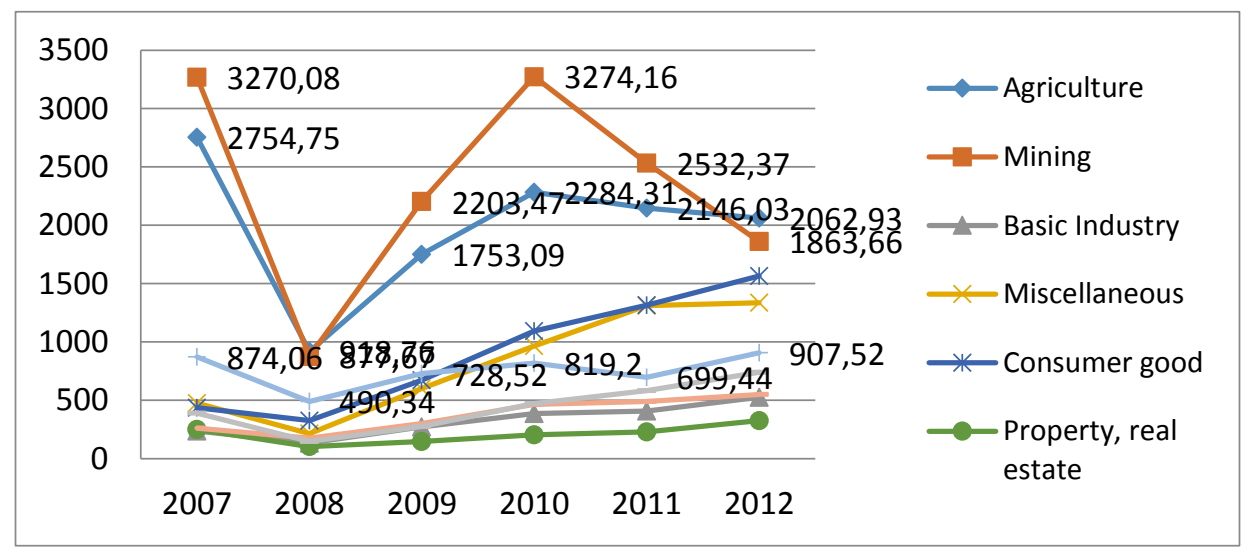

Sumber: Bursa Efek Indonesia

Berdasarkan Gambar 1 harga saham dari seluruh perusahaan terdaftar di Bursa Efek Indonesia yang diklasifikasikan menjadi 9. Industri cenderung mengalami peningkatan mulai dari tahun 2008 hingga 2012 kecuali agriculture dan mining yang mengalami penurunan di tahun-tahun terakhir. Perusahaan pertambangan merupakan perusahaan yang mengalami peningkatan harga saham paling tinggi sekaligus mengalami penurunan yang sangat rendah. Terdapat 10 perusahaan pertambangan yang terdaftar di Bursa Efek Indonesia yang secara rutin mempublikasikan laporan keuangan. Harga saham pertambangan periode 20082012 dapat dilihat pada Gambar 2.

\section{Gambar 2. Harga Saham Pertambangan 2008-2012}

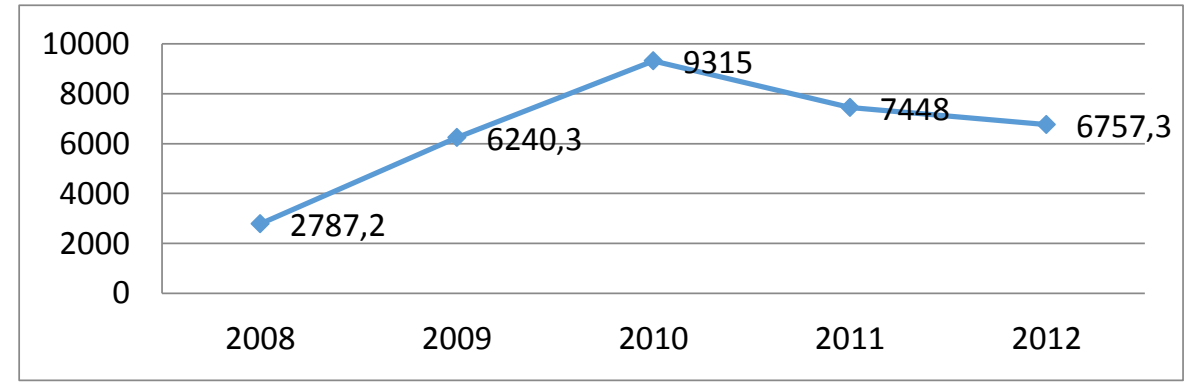

Sumber : Bursa Efek Indonesia 
Harga saham pertambangan yang cenderung menurun di beberapa tahun terakhir jika terus dibiarkan akan mengganggu pertumbuhan perusahaan di masa mendatang. Investor cenderung tidak melirik perusahaan dengan saham yang rendah karena saham yang rendah menandakan bahwa kondisi dan kinerja perusahaan kurang optimal. Semakin tinggi harga saham semakin tinggi pula nilai perusahaan.

Van Horne, James C, dan Jhon M (2005) menyatakan harga saham dapat dipengaruhi oleh dividen karena kebijakan dividen memberikan informasi mengenai profitabilitas perusahaan. Perusahaan harus berupaya untuk memutuskan kebijakan dividen yang optimal guna mensejahterakan pemegang saham dan memajukan perusahaan. Bringham dan Houston (2010) berpendapat bahwa "kebijakan dividen yang optimal pada suatu perusahaan adalah kebijakan yang menciptakan keseimbangan antara dividen saat ini dan pertumbuhan perusahaan dimasa yang akan datang."
Kebijakan dividen merupakan keputusan perusahaan yang berkaitan dengan proporsi penggunaan laba untuk dibagikan kepada pemegang saham dalam bentuk dividen atau laba ditahan untuk pembiayaan investasi di masa mendatang. Besaran dividen yang dibagikan kepada pemegang saham secara stabil atau meningkat akan meningkatkan kepercayaan investor karena hal tersebut secara tidak langsung memberikan informasi kepada para investor bahwa kemampuan perusahaan dalam menghasilkan laba semakin meningkat.

Penentuan proporsi laba yang dibagikan dalam bentuk dividen disebut Dividend Payout Ratio (DPR). Semakin besar porsi dividen yang dibagikan maka semakin besar pula tingkat DPR. Sebaliknya, jika porsi laba ditahan semakin besar maka DPR akan semakin rendah. Melalui besaran DPR dapat dilihat prospek perusahaan dimasa yang akan datang. Adapun gambaran dividen perusahaan pertambangan tahun 20082012 pada Gambar 3.

Gambar 3. DPR Perusahaan Pertambangan 2008-2012

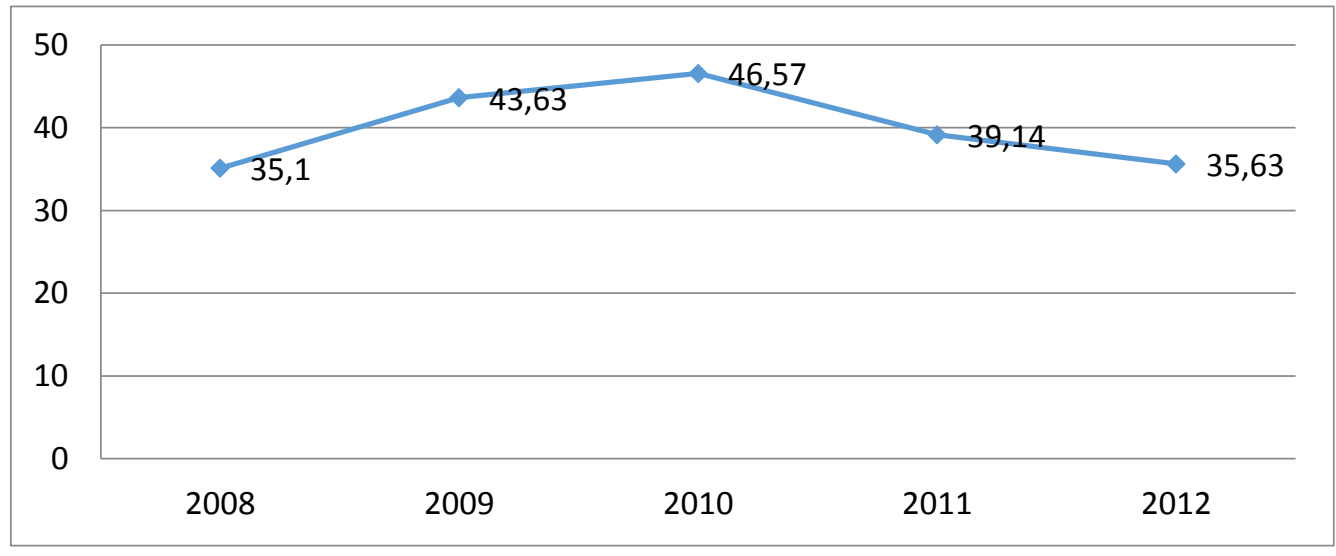

Sumber: Bursa Efek Indonesia

Berdasarkan Gambar 3 dapat dilihat rata-rata DPR 10 perusahaan pertambangan yang terdaftar di Bursa Efek Indonesia cenderung menurun. Penurunan terjadi mulai tahun 2011 sebesar 39,14\% hingga tahun 2012 mencapai 35,63\%. Menurunnya DPR pertambangan ini diikuti pula dengan penurunan harga saham. Naiknya DPR perusahaan pertambangan juga diikuti dengan naiknya harga saham pertambangan. Fenomena akan perubahan harga saham tersebut menjadi pertanyaan tersendiri apakah kebijakan dividen berpengaruh terhadap harga saham. 


\section{Kajian Literatur}

Kondisi pasar modal saat ini sedang berkembang pesat sangat menarik perhatian para calon investor dan pemilik modal untuk berinvestasi di pasar modal. Namun sebelum memutuskan untuk memiliki suatu saham perusahaan tentunya membutuhkan informasi yang berkaitan dengan dinamika harga saham. Dinamika harga saham suatu perusahaan dapat dilihat dari harga penutupan saham. Menurut Suad Husnan (2009) jika pasar bursa efek sudah tutup maka harga pasar adalah harga penutupannya (closing price) jadi harga pasar inilah yang menyatakan naik turunnya suatu saham. Para manajer dapat melakukan maksimalisasi nilai perusahaan dengan menetapkan kebijakan yang baik dan benar (Baker et al, 2009).

Perusahaan dengan harga saham yang tinggi mencerminkan bahwa kinerja dari perusahaan tersebut baik untuk dapat menciptakan harga saham yang tinggi, perusahaan sebelumnya harus terlebih dulu mencari tahu mengenai faktor-faktor yang dapat mempengaruhi harga saham. Salah satu faktor yang dapat mempengaruhi harga saham adalah kebijakan dividen. Aspek utama dari kebijakan dividen adalah menentukan alokasi laba perusahaan yang tepat antara dibagikan menjadi dividen atau ditahan untuk reinvestment perusahaan.

Bringham dan Houston (2010) berpendapat bahwa kebijakan dividen yang optimal pada suatu perusahaan adalah kebijakan yang menciptakan keseimbangan antara dividen saat ini dan pertumbuhan perusahaan dimasa yang akan datang.

Kebijakan yang diambil oleh perusahaan tentunya akan sangat berpengaruh pada nilai perusahaan, dividen adalah kebijakan yang diambil manajemen perusahaan untuk memutuskan membayar sebagian keuntungan perusahaan kepada pemegang saham daripada menahannya sebagai laba ditahan untuk diinvestasikan kembali agar mendapat capital gains (Ambarwati,
2010). Dalam hal ini dividen merupakan salah satu jenis kebijakan finansial yang berhubungan dengan distribusi keuntungan kepada pemegang saham.

James C. Van horned dan john M. wachowicz. JR (2005) berpendapat bahwa "dividen digunakan para investor sebagai prediktor kinerja perusahaan dimasa yang akan datang. Konsep sinyal keuangan menyatakan bahwa dividen memiliki pengaruh terhadap harga saham karena memberikan informasi atau sinyal mengenai profitabilitas perusahaan."

Penelitian terdahulu menunjukan adanya premis antara dividen dengan nilai perusahaan. Kanwal Iqbal Khan (2008) dalam jurnalnya "Effect of dividends on prices: A case of chemical and Pharmaceutical Industry of Pakistan" menyatakan bahwa dividen, return on equity (ROE) berpengaruh pada harga saham.

\section{Metode Penelitian}

Metode yang digunakan dalam penelitian ini adalah metode penelitian deskriptif dan metode verifikatif. Sumber data yang digunakan dalam penelitian ini adalah sumber data sekunder. Sampel dalam penelitian 10 perusahaan yang terdaftar di BEI tahun 2008-2012, teknik pengambilan secara purposive sampling.

\section{Hasil dan Pembahasan}

Berdasarkan hasil analisis deskriptif harga saham perusahaan pertambangan yang terdaftar di Bursa Efek Indonesia tahun 2008-2012 cenderung menurun pada dua tahun terakhir. Penurunan harga saham disebabkan oleh semakin menurunnya rata-rata pembagian dividen yang dilakukan perusahaan pertambangan. Perusahaan pertambangan yang terdaftar di Bursa Efek Indonesia lebih memilih untuk menginvestasikan kembali laba yang diperolehnya dengan harapan untuk mendapatkan laba yang lebih besar sebelum perusahaan membaginya dalam bentuk dividen kepa- 
da para pemegang saham.

Adapun hasil analisis verifikatif dengan menggunakan regresi linear sederhana untuk meramalkan pengaruh kebijakan dividen terhadap harga saham. Tabel 1 mengenai output koefisien regresi.

Tabel 1. Koefisien Regresi

\begin{tabular}{cccccc} 
Model & B & Std. Error & Beta & T & Sig. \\
\hline (Constan) & 24.729 & 885.151 & & .028 & .978 \\
& & & & & \\
\hline DIVIDEN & 49.246 & 18.956 & .676 & 2.598 & .032
\end{tabular}

Berdasarkan hasil perhitungan, diperoleh persamaan regresi liner antara dividen dan nilai perusahaan yaitu sebagai berikut:

\begin{tabular}{|l|}
\hline Y $=\mathrm{a}+\mathrm{Bx}$ \\
Harga saham $=24.729+49.246$ kebijakan \\
dividen
\end{tabular}

Arti persamaan rumus tersebut yaitu nilai konstanta 24.729 mengandung arti jika kebijakan dividen tidak mengalami perubahan maka nilai harga saham sebesar 24.729. Nilai koefisien untuk kebijakan dividen sebesar 49.246. Nilai ini menunjukkan bahwa setiap terjadi penambahan dividen sebesar 1 persen, maka akan terjadi peningkatan harga saham sebesar 49.246 kali. Dengan melihat dari persamaan maka ada pengaruh positif atau searah kebijakan dividen terhadap harga saham. Hal ini menunjukkan bahwa naiknya kebijakan dividen akan diikuti dengan kenaikan harga saham, sebaliknya turunnya kebijakan dividen maka harga saham akan ikut menurun.

Pengumuman dividen dapat dijadikan informasi oleh pemegang saham mengenai kinerja perusahaan sehingga diharapkan dapat mendorong harga saham. Dividend signaling theory menjelaskan bahwa informasi pengumuman dividen dapat digunakan oleh investor sebagai sinyal mengenai prospek perusahaan di masa mendatang. Sutrisno (2003) menyatakan bahwa apabila dividen yang diterima naik tentu saja hal ini akan membuat investor tertarik untuk membeli saham perusahaan. Dengan banyaknya saham yang dibeli maka harga saham perusahaan akan naik. Investor dalam menginvestasikan dananya akan dihadapkan pada ketidakpastian yang tinggi dari hasil investasinya, maka dari itu informasi mengenai naik turunnya dividen tunai merupakan suatu informasi yang penting bagi investor, karena dalam informasi tersebut terkandung muatan informasi yang berkenaan dengan hasil investasinya dimasa yang akan datang. Hal tersebut sejalan dengan pendapat Hartono (2010) yang menyatakan umumnya perusahaan emiten menggunakan pembayaran dividen sebagai sinyal kepada pelaku pasar. Dengan meningkatkan nilai dividen yang dibayar, perusahaan emiten mencoba memberi sinyal bahwa perusahaan mempunyai prospek yang baik dimasa depan. Sebaliknya, pemotongan nilai dividen oleh perusahaan akan dianggap sebagai sinyal buruk karena akan dianggap sebagai kekurangan likuiditas.

Pengumuman dividen merupakan salah satu informasi dalam pasar modal yang efisien. Informasi yang relevan ini dapat mempengaruhi harga saham di pasar modal, seperti yang dinyatakan dalam teori effeciency market hypothesis, harga saham bereaksi terhadap suatu informasi yang ada, termasuk didalamnya adalah informasi pembagian dividen. Pembayaran dividen yang tinggi cenderung akan meningkatkan harga saham, begitu juga sebaliknya. Informasi 
tentang pembagian dividen dipercaya akan dapat mempengaruhi harga saham di lantai bursa akibat dari aksi investor yang menginginkan keuntungan dari kejadian tersebut. Berdasarkan penelitian ini kebijakan dividen memiliki kandungan informasi yang berguna bagi investor. Hal ini berdampak pula pada perusahaan yang akan memberikan tanda ke pasar bahwa perusahaan memiliki kemampulabaan yang tinggi dan prospek ke depan yang bagus, yang akan mampu mempertahankan tingkat pembayaran dividennya.

Hasil penelitian ini mendukung penelitian Mohammad Hashemijoo, et.al (2012); Ather Azim Khan (2010); Daniel Sehate Sembiring (2009); Nuriken D.P Harahap (2011); Douglas S. Laabs \& Frank W. Bacon (2013); Neetu modal (Myers dan Majluf 1984), sehingga dapat dikatakan bahwa dividen dapat dipandang sebagai sinyal terhadap prospek perusahaan (Miller dan Rock 1985).

Penelitian ini tidak sejalan dengan penelitian Kanwal Iqbal Khan (2010); Febri Rahmadsyah Harahap (2012) yang menunjukkan hasil kebijakan dividen tidak memiliki pengaruh terhadap harga saham.

\section{Kesimpulan}

Berdasarkan uraian di atas maka kesimpulan dalam penelitian ini bahwa kebijakan dividen terbukti berpengaruh positif dan signifikan terhadap harga saham. Hasil penelitian ini juga mendukung pandangan kerelevanan dividen (dividend relevance theory) dan menolak pandangan ketidakrelevanan dividen (irrelevance dividend theory). Hasil penelitian ini sesuai dengan teori signal bahwa dengan adanya kebijakan dividen memberikan sinyal baik terhadap investor.

Adanya keterbatasan peneliti dalam melakukan penelitian, bagi para peneliti selanjutnya yang akan meneliti harga saham, sebaiknya melihat faktor-faktor
Mehndiratta \& Shuchi Gupta (2010); Einde Evana (2008); Anthanasios Vazakidis \& Stergios Athianos (2010) yang menemukan kebijakan dividen berpengaruh terhadap harga saham. Penelitian ini sesuai dengan teori signal dan mendukung teori dividen relevan. Penelitian ini sejalan dengan penelitian Black dan Scholes (1974) yang telah menemukan bahwa perusahaan yang meningkatkan pembayaran dividen dapat mengharapkan akan ada efek pasti pada harga saham. Harga saham berubah sebagai tanggapan atas perubahan dividen, karena pasar mungkin percaya bahwa perubahan menunjukkan sesuatu tentang kemungkinan penghasilan masa depan. Dividen dapat membantu memberikan informasi yang baik mengenai manajemen perusahaan ke pasar lain yang dapat mempengaruhi harga saham yang belum diteliti dalam penelitian ini dengan sektor perusahaan yang berbeda, serta menambah periode pengamatan.

\section{Daftar Pustaka}

Ambarwati, S. D. A. (2010). Manajemen Keuangan Lanjut. Yogyakarta: Graha Ilmu.

Baker, H. K., Singleton, C.,Veit, E. T. (2009). Survey Research in Corporate Finance: Bridging Thr Gap between Theory and Practice. New York: Oxford University Press.

Black, F., \& Scholes, M. (1974). The Effect of Dividend Yield and Dividend Policy on Common Stock Prices and Return, Journal of Financial Economics, 1(1), 1-22. doi: https://doi.org/10.1016/0304405X(74)90006-3

Brigham, E. F. \& Houston, J. F. (2010). Fundamentals of Financial Management. Singapore: Cengage Learning Asia Pte LTD. 
Khan, A. A. (2010). Dividend Policy and Stock Price: A Case of KSE-100 Index Companies. Faculty of Commerce. The University of Central Punjab. Diakses dari https://pdfs.semanticscholar.org/669 a/43da6a7bc7088f305302e021661b 715ac145.pdf

Mehndiratta, N. \& Gupa, S. (2010). Impact of Dividend Announcements on Stock Price. Journal of Business Studies Quarterly 2010, 4(1). Diakses dari http://www.csjournals.com/IJITKM $\underline{\text { PDF\%203-1/47.pdf }}$

Sembiring, D. S. (2009). Pengaruh Perubahan Struktur Modal dan Dividen Payout Ratio terhadap Perubahan Harga Saham pada Lembaga Keuangan di Bursa Efek Indonesia. Tesis. Universitas Sumatera Utara. Medan. Diakses dari

http://repository.usu.ac.id/handle/12 $\underline{3456789 / 18430}$
Miler, M. H. \& Rock, K. (1985). Dividend Policy Under Asymmetric Information. Journal of Finance 40(4), 1031-1051. doi: https://doi.org/10.2307/2328393

Myers, S. C. \& Majluf, N. S. (1984). Corporate Financing and Investment Decisions When Firms Have Information that Investors Do Not Have. Journal of Financial Economics 13(2). 187-221. doi: https://doi.org/10.1016/0304405X(84)90023-0 